Publisher homepage: www.universepg.com, ISSN: 2707-4641 (Online) \& 2707-4633 (Print)

https://doi.org/10.34104/ijma.020.074095

International Journal of Management and Accounting

Journal homepage: www.universepg.com/journal/ijma

\title{
Effect of Electronic Marketing on Customer Satisfaction: The Case of Four Star Hotels in Addis Ababa
}

\author{
Abel Mezgebe* \\ Department of Marketing Management, Mekelle University, Mekelle, Ethiopia. \\ *Correspondence: mezgebeabe187@gmail.com
}

\begin{abstract}
The main objective of this study was to determine the effect of e. marketing on customer satisfaction towards the service provided by four- star hotels in Addis Ababa, Ethiopia. A researcher used a probability technique which is systematic for the study a total of 260 questioners were distributed to the customer of the four international hotels which rated as four-star in Addis Ababa the response rate of 241 participants was collected which is a 92.7 percent response rate achieved and descriptive statics was used firstly to illustrate the main features of a data set in quantitative terms. The mean value for all variables ranged from 3.33 to 3.57, the standard deviation 0.651 to .736 kurtosis, and the skewness test demonstrated as the distribution was normal. The correlation analysis illustrated the relationship between location facet, technological facet, social skill, and customer satisfaction was moderately correlated ( $\mathrm{r}=0.482, \mathrm{r}=0.397$ and $\mathrm{r}=0.477$ ) respectively, the relation between motivation, technical skill, and customer satisfaction was strongly correlated ( $\mathrm{r}=0.635$ and $\mathrm{r}=0.68$ ) respectively and all were tested as statistically significant (sig. (2tailded $=000$ ). The final test was done by regression analysis the result indicated that the effect of location facet, technological facet, and social skill overall insignificant (sig. $0.177,0.105$, and 0.892 respectively) the effect of motivation (sig. 000) and technical skill (sig.000) the major finding Location facet, technological facet, and social skill are insignificant and also rejected on the other way the two variables (motivation and technical skill) has a significance, positive and also supported influence on customer satisfaction. Consequently, the researcher recommends for the management of the hotel to focus on the above statistically significant factors in order to satisfy their customers' as well to make them loyal.
\end{abstract}

Keywords: Customers'satisfaction, Selection factors, Electronic marketing, and Customer satisfaction.

\section{INTRODUCTION:}

The theories regarding e-marketing haven't been unified yet, because an oversized diversity in specialists' opinions. Still, one of the aspects that is established and has ceased being discussed in contradictory is the fact that electronic marketing first appeared under the form of various techniques utilized by companies distributing their products through online channels. The e-tailors, in their fever, have left behind an improbable "soup" of techniques that slowly begins to get cleared and shaped (Kotler $\&$ Gary, 2005). In early 90's, the marketing theory re-oriented towards the relational exchanges para- digm, mainly because marketing used to give more importance to gaining new customers rather than retaining the existing ones. Studies performed have indicated that the major economic benefits come from raising fidelity among customers as a result of customer retention. This is the perspective that led to the apparition of the relational marketing, which is based on the necessity of developing interactions with individual customers. The marketing management advanced by Philip Kotler promotes the idea of the transactional marketing being included into a larger concept, that of relational marketing. Such an enlarged perspective would see marketing as a relation made of continuous series of interactive 
collaborations with each individual customer (Kotler \& Gary, 2005).

The hotel industry has a long colorful history beginning with inns, and lodges, and eventually evolving into the hospitality industry (Kasavana and Brooks, 2001). A tremendous change in the tourism industry has brought significant change in the hotel business. This means that the expansion and development of travel has contributed a lot to the development of the hotel industry. Among the changes in the hotel industry, Ethiopia's hotel industry has expanded and developed drastically into a new level of the hotel business, considering Ethiopia is one of the main attractions for tourists around the world. Hotels are magnificent works of architecture, true landmarks in their community. They are also a part of a very competitive industry, and this affects how they need to be managed in terms of the services they provide for their customers or guests. Hotels are labor-intensive business, where many employees provide service to many guests, and the services provided are a very personal nature (Nebel, Eddystone, 1991).

Most of the hotels in Ethiopia are based in the capital city, Addis Ababa. They are located around the Bole International Airport, which is located in the South East of the capital city. The researcher selective hotels are a four star hotel conveniently located at the heart of Bole, Friendship International Hotel is a luxurious 4-star hotel located in Addis Ababa. And also Siyonat is a newly opened hotel located just 2minutes' drive away from Bole International Airport. New hotels are opening at a fastest rate in Addis Ababa. These new hotels will soon open their doors to provide services for guests (Friendship International Hotel, 2013).

1.1 Statement of problem - Globally, the hotel sector is exploiting the e-marketing potential to market and expand its border lines. This is because e- marketing offers hotels a channel to display their services to potential customers. However most of the general managers and Marketing managers in Ethiopia overlooked the benefit of internet marketing to develop new target markets and to deprive strategy hence only few of the hotels have utilized the Internet to attract potential target market. Rather they preferred to clutter with newspapers, TV, radio etc. According to 2013 report of MOCT, over $90 \%$ of the guests of hotels in Ethiopia is foreign tourists UniversePG I www.universepg.com
(Tourism Statistics Bulletin 2009-2012, 2013). EMarketing is deemed to be broad in scope, because, not only refers to marketing and promotions over the Internet, but also includes marketing done via e-mail and wireless Medias (Hossain et al., 2020). In Ethiopia most private and government hotels are not yet practicing E-marketing. Most of the hotels have not used or practice on E-Marketing because of the following problem: (Grybniak, 2014).

- Hotels' information system is not computerized and it is difficult to run the company competitively, efficiently, and profitably.

- Lack of financial capability or resources.

- Lack of knowledge or skill about the usage.

- Lack of awareness about the overall benefit of E-Marketing for an organization and customers.

However, e-marketing is still a relatively new concept, particularly for organizations operating in developing countries that have limited resources, bad infrastructure, and strong competition and cannot afford to make unwise investments or wrong decisions like the Ethiopian business organizations operate. In contacting or booking system Emarketing plays a great role for both the firms and customers for more flow of information. Empirical Study conducted by (Sisay, 2016) suggested that emarketing and customer satisfaction in four star hotels would be strongly affected by level of information. Furthermore, previous study paid no attention to other effects like Location and Technological facets, social skill, Motivation and Technical skill on customer satisfaction. Hence this paper gives a better understanding about How Location facets and Technological facets, social skill, Motivation and Technical skill affect customer satisfaction in four star hotels in Addis Ababa.

1.2 Research Question - The paper has the following main and sub research questions to address the objectives of Electronic Marketing in the hotel industry four star hotels in Addis Ababa. How does e-marketing influence customer satisfaction in four star hotels in Addis Ababa? How does a Location facet affect customer satisfaction in four star hotels in Addis Ababa? Others sub-questions are -

- How does a Technological facet affect customer satisfaction in four star hotels in Addis Ababa? 
- How does Social skill affect customer satisfaction in four star hotels in Addis Ababa?

- How does Motivation affect customer satisfaction in four star hotels in Addis Ababa?

- How does Technical skill affect customer satisfaction in four star hotels in Addis Ababa?

1.3 Objective of the study - The general objective of the study is, to determine the effects of Electronic Marketing on customer satisfaction in four star hotels in Addis Ababa. The specific objectives of the study are:-

- To examine the effects of location facets on customer satisfaction in four star hotels in Addis Ababa.

- To analyze the effect of Technological facets on customer satisfaction in four star hotels in Addis Ababa.

- To test the effects of social skill on customer satisfaction in four star hotels in Addis Ababa.

- To examine the effects of motivation on customer satisfaction in four star hotels in Addis Ababa.

- To analyze the effect of Technical skill on customer satisfaction in four star hotels in Addis Ababa

1.4 Hypo research of the study - With the specific objectives stated above, the following hypo research are formulated

H1: Location facets have a positive and significant effect on customer satisfaction in four star hotels in Addis Ababa.

H2: Technological facets have significant and positive effect on customer satisfaction in four star hotels in Addis Ababa.

H3: There is a positive and significant relationship between social skill and customer satisfaction in four star hotels in Addis Ababa.

H4: Motivation positively and significantly affects customer satisfaction in four star hotels in Addis Ababa.

H5: Technical skills have a positive and significant effect on customer satisfaction in four star hotels in Addis Ababa.

1.5 Significance of the study - This research expected to provide base line information about the effects of Electronic Marketing for star hotel sectors and other sectors who engage in Electronic marke- ting to satisfy their customers. The aim of this research is to analyze the effect of using the electronic marketing Strategies among hotels in Ethiopia, specifically of four-star hotels in Addis Ababa. The Researcher expected the research to show whether four-star hotels in Addis Ababa are over, under or properly utilizing the potential of the electronic marketing accordingly, based on the findings of the research for those hotels which are not utilizing the potential, the research suggests they should engage the services of e. marketing with professionals to develop a comprehensive e-marketing strategy so as to take full advantage of the benefits associated with e. marketing.

1.6 Delimitation/Scope of the Study - Geographically this research is carried out in Addis Ababa, specifically four-star hotels. This is done through probability sampling method, as most of the target population's with visible reality for anyone are located in these areas. The reason behind them being located in these two vicinities is because of the location of direct and indirect target markets. Geographically, this research was limited to Addis Ababa only. This was due to two major reasons. One was because of time, money and experience shortage from the side of the researcher to make a country wide research. The second was because, most countries in Africa, except South Africa, have internet infrastructure only in their major cities and usage is highly limited to urban areas due to knowhow and infrastructural factors (Hossain, 2020). Thus, a sample drawn from this city would be most likely representative of the population that makes use of the internet. The researcher followed qualitative research and used mainly descriptive data analysis methodology while to some extent correlation.

1.7 Time interval - The research carried out from October, 2016 to June, 2017

1.8 Limitation of the study - Although there are many four star hotels in Addis Ababa all over the country, due to time and budgetary constraints the study was limited to service delivery practices of four star hotels in Addis Ababa only. Again because of the limited resources, only customers' perceptions will be taken i.e. the study was confined to customers' point of view only. The service firm's or employee's perspectives about the subject was not researched. 
1.9 Organization of the study - The paper is organized in to five main chapters with important concepts related to the study. Chapter one deals with introduction, which contains background of the study, statement of the problem, general and specific objective of the study, significance of the study, scope of the study, limitation of the study, which includes organization of the study were presented in this chapter. Chapter two provides the literature part. The third chapter describes the research methodology in detail. Chapter four is concerned with results and discussions. Finally, chapter five brings an end of this study with summary of the research findings, conclusion and possible recommendations.

\section{Literature Review}

E-Marketing or electronic marketing refers to the application of marketing principles and techniques via electronic media and more specifically the Internet. The terms e-Marketing, Internet marketing and online marketing, are frequently interchanged, and can often be considered synonymous. EMarketing is the process of marketing a brand using the Internet. It includes both direct response marketing and indirect marketing elements and uses a range of technologies to help connect businesses to their customers. By such a definition, e-Marketing encompasses all the activities a business conducts via the worldwide web with the aim of attracting new business, retaining current business and developing its brand identity (American Marketing Association, 2008).

2.1 E-marketing and hotel industry - E-marke-ting is the new trend of marketing extensively needed by hotel industry. The traditional marketing strategy of hotel industry now not performing very well; in place e-marketing is taking the driver's seat. The travel industry survives as one of the better performing sectors in e-commerce. With no fulfilment and no need for online payments, the hotel industry is well positioned to capture the full potential of ecommerce while avoiding many of its risks. "Currently, in Hong Kong, China, Taiwan and South Korea, approximately 5\% to $10 \%$ of all lodgings are booked through the Internet, with 2004 estimates approaching 20\%. This would follow the U.S. trend where hotels are reporting that up to $30 \%$ of all lodging is booked through online channels. Despite the burst of the Internet bubble, the promise of the Internet for hoteliers is still real: Online distribution can minimize costs, attract affluent customers and lessen dependency on more traditional and expensive distribution channels" (Iacovou, 2004).

2.2 Service quality and customer satisfaction in hotel industry - The primary function of the hotel units is to provide quality service to its customers. Service quality is defined as how well customers needs are met, and how well the service offered meets the customers' expectations. (Kendall, Stephanie, 2007) has shown that the perceived quality of service is a function of the comparison of expected service with perceived service, in other words is the result of a comparative evaluation process. (Parasuraman et al., 1985) Has defined "quality of service" as the degree and direction of discrepancy between perceptions and expectations of their customers, where perceived service quality is the gap between customer's expectations and perceptions as measurement of service quality. Smaller the gap, the better is the quality of service and greater customer satisfaction.

2.3 Measuring customer satisfaction: The main reason for measuring customer satisfaction is to collect information from one side to see what customers require to be done differently and in turn to assess how client needs are met. According to the literature customer satisfaction measurement is done in different ways, for example one of the ways is to include a single question in customer satisfaction questionnaire: "In general, how satisfied are you with...?" where responses of the questionnaire questions are made according to a system with 7 degrees from " very satisfied" (coded 1) to "very Satisfied " (coded 7), known as Likert scale. (Schneider and Bowen, 1995; Heskett et al., 1997) have developed a theory for the measurement of customer satisfaction based on key elements of satisfaction in service and price, but their valuation is done independently through the "index-service" and "price-index". However, some researchers suggest that a number of hotels $10^{\text {th }}$ International conference of ASECU 166 chains use assessment methods for customer satisfaction based on improper practices to take important managerial decisions (Barsky, 1992). Therefore is required to apply a more scientific method to use the GCCs in order to make fair and appropriate managerial decisions (Barsky and Huxley, 1992). Despite the different types of cust- 
omer satisfaction systems, they generally have some common mistakes (Gilbert \& Horsnell, 1998). EMarketing performance measures. Namely; Financial measures; Competitive market measures; Consumer behavior measures; Consumer intermediate measures; and E-marketing measures, such as Conversion rate, Traffic, Visit duration, Number of transactions, and Number of users.

Technological Facets - Electronic Commerce or ecommerce has received much attention from governments, businesses and regional organizations or institutions. These costs are generated from hard ware and software installations, maintenance costs, labor costs, etc. Scalability, reliability, and security: The increased loads of data transactions and storage as well as the traffic of applications such as audio, streaming video and graphics, drive managers to develop strategies to manage those various issues (Andrlić, 2007). It is with the latter that we are concerned with (Lonelyplanet, 2011). The World Wide Web is a cost effective means for enterprises in the travel and tourism sector to directly market their offerings to a large customer population across the globe. It is also a very convenient means for the customers to gather information and compare between alternatives in an interactive manner (Hensens et al., 2010).

Location Facets - In the hotel industry, the geographic location of a hotel has a major relationship on its operations and profitability. Thus based on the profile of a hotel's visitors, the size of the market, or the intensity of competition, hotels may differ in their levels of ICT adoption propensity (Nebel, Eddystone, 1991). Many hotels used Internet to promote the hotel and to provide information about prices. In their study for the evaluation of Internet websites of Accommodation Establishments in Turkey, (Kasavana and Brooks, 2001) stress that the use of Internet websites for communication of marketing of products offered by accommodation establishments is quite new. (Dahlen, Micael, 2010) Found that firms benefited superficially from marketing communication activities at their websites and used various electronic marketing activities at elementary stage. In a study by (Chris Chatwin, 2013) that examined the websites of some 65 hotels in Singapore, it was determined that online booking; online payment, fast discount and online confirmation opportunities; restaurant promotions; and family-child promotions took place at the websites UniversePG I www.universepg.com of the hotels within the scope of the study at the rates of $95 \%, 83 \%, 49 \%$ and $3 \%$, respectively. In her study on the role of Internet in destination marketing, (Owen, Bhris, 2015) stated that tourism marketers benefited intensively from the opportunities provided by technological developments in the field of destination marketing as well and that they gave up the traditional marketing understanding and were headed for a modern marketing understanding. In a study by (Cox \& Koelzer, 2004) on ecommerce practices in tourism sector in and around Nevsehir, it was found that costs decreased and productivity increased upon the commencement of the use of information and technology in accommodation establishments. It was stressed that the use of computer-based automation was at the rate of $88 \%$ at the front office department of the hotels located at the surveyed site and that competitive advantage in the tourism sector might be provided using information and technology Dilekkeke cmorkoc and lutfiatay188 In their study on the content analysis of hotels' websites, (Peštek and Čičić, 2010) analyzed the websites of some 286 four- and five-star hotel establishments. (Kendall, Stephanie, 2007) indicates that consumers or travel agents have opportunity to create, manage and update itineraries.

\subsection{Marketing strategy in the digital age: Doing} business in the new digital age will call for a new model for marketing strategy and practice. The internet is revolutionizing how companies create value for customers and build customer relationships. The digital age has fundamentally changed customers' notions of convenience, speed, price, product information and service. Thus to days' marketing requires new thinking and action. Companies need to retain most of the skill and major new competencies and practices if they hope to grow and prosper in the new environment (Kotler \& Gary, 2005).

\subsection{E-Business, E-Commerce, and E-Marketing in the digital age: According to (Kotler \& Gary, 2005)} has defined E-business involves the use of electronic platforms intranets, extranets, and the internet to conduct a company's business. Companies also set up extranets with their major suppliers and distributers to enable information exchange, orders, transactions, and payments. According to (Kotler \& Gary, 2005) has defined E-commerce is more specific than e-business and also defined E-marke- 
ting is the marketing side of e-commerce. It consists of company efforts to communicate about, promote, and sell products and services over the internet. Thus Amazon.com, LLBean.com and Dell.com conduct emarketing at their web sites. E-commerce and the internet bring many benefits to both buyers and sellers. Let's review some of these major benefits:

2.5.1 Benefits of Buyers - Buying via internet benefits both final buyers and business buyers in many ways. It can be convenient; customers do not have to battle traffic, find parking spaces, and trek through stores and aisles to find the examiner products. They can do comparative shopping by surfing web sites. Web marketers never close their doors. Buying is easy and private; customers encounter fewer buying hassles and do not have face salespeople or open themselves up to persuasion and emotional pitches. Buyers often can interact with the seller's site to create exactly the configuration of information, products, or services they desire, then order or down load them on spot. Moreover, the internet gives consumers a greater measure of control. Like nothing else before it, the internet has empowered consumers.

2.5.2 Benefits of Sellers - E-commerce also yields many benefits to sellers. First, the internet is a powerful tool for building a customer relationship. Because of its one-to-one, interactive nature, companies can interact online with customers to learn more about specific needs and wants. Online customers can ask question and volunteer feedback. Based on this ongoing interaction, companies can increase customer value and satisfaction through However, an online catalogue can be adjusted daily or even hourly, adapting product assortments, prices and promotions to match changing market conditions. Finally, the internet is a truly global medium that allows buyers and sellers to click from one country to another in seconds (Kotler \& Gary, 2005).

2.6 E-Marketing Domains - The four major emarketing domains are $\mathrm{B} 2 \mathrm{C}$ (business to consumer), $\mathrm{B} 2 \mathrm{~B}$ (business to business), $\mathrm{C} 2 \mathrm{C}$ (consumer to consumer), $\mathrm{C} 2 \mathrm{~B}$ (consumer to business).

2.6.1 B2C (Business-to-Consumer) - B2C (business-to-consumer) e-commerce: is the online selling of goods and services to final consumers. Despite some gloomy predictions, online consumer buying continues to grow at a healthy rate. By 2009, consumers worldwide spent more than $\$ 167$ billion online. In the United States alone, consumer spending online is expected to exceed $\$ 316$ billion by 2010. The largest categories of consumer online spending include travel service, clothing, computer hardware and software, consumer electronics, books, music and video, health and beauty, home and garden, flowers and gifts, sports and fitness equipment and toys.

\subsubsection{B2B (Business-to-Business) - Using Business} to Business trading networks, auction sites, spot exchanges, online product catalogs, barter sites, and other online resources to reach new customers, serves current customers more effectively, and obtains buying efficiencies and better prices. Most major B2B marketers now offer product information, customer purchasing and customer support service online. Some B2B e-commerce takes place in open trading exchange and private trading exchanges.

Open trading exchange: huge e-marketers in which Business to Business buyers and sellers find each other online, share information and complete transaction efficiently.

Private trading exchange: Business to Business trading networks that link a particular seller with its own trading patterns. Rather than simply completing transactions, private exchanges give sellers greater control over product presentation and allow them to build deeper relationship with buyers and sellers by providing value-added services.

2.6.3 C2C (Consumer-to-Consumer) - C2C (consumer to-consumer) e-commerce:-is online exchanges of goods and information between final consumers. The internet provides an excellent means by which consumers can buy or exchange goods or information directly with one another. $\mathrm{C} 2 \mathrm{C}$ involves interchanges of information through internet forums appeal to special interest groups. Such activities may be organized for commercial or non-commercial purposes.

2.6.4 C2B (Consumer-to-Business) - C2B (consumer-to-business) e-commerce: online exchanges in which consumers search out sellers, learn about their offers and initiate purchases, sometimes even driving transaction term (Kotler \& Gary, 2005).

2.7 Setting up an E-Marketing Presence - Clearly all companies need to consider moving into emarketing. Companies can conduct e-marketing in 
any of the four ways: creating a Web site, placing ads online, setting up or participating in Web communities, or using e-mail.

2.7.1 Creating a Web site - For most companies, the first step in conducting e-marketing is to create a Web site. However, beyond simply creating a Web site, marketers must design an attractive site and find ways to get consumers to visit the site, stay around, and come back often.

2.7.2 Types of Web Sites - Web sites vary greatly in purpose and content. The most basic type is a corporate web site. These sites are designed to build customer goodwill and to supplement other sales channels, rather than to sell the company's products directly. Corporate Web sites typically offer a rich variety of information and other features in an effort to answer customer questions, build closer customer relationships, and generate excitement about the company (Islam et al., 2020). These sites engage consumers in an interaction that will move them closer to a direct purchase or other marketing outcome. Companies aggressively promote their marketing Web sites in offline print and broadcast advertising and through banner-to-site ads that pop up on other Web sites.

\subsubsection{Designing Effective Web Sites - Creating a}

Web site is one thing: getting people to visit the site is another. The key is to create enough value and excitement to get consumers to come to the site, stick around, and come back again. A key challenge is designing a Web site that is attractive on first view and interesting enough to encourage repeat visits. The early text-based Web sites have largely been replaced in recent years by graphically sophisticated Web sites that provide text, sound, and animation. To attract new visitors and to encourage revisits, suggests one expert, e-marketers should pay close attention to the seven Cs of effective Web site design:

Context: the sites layout and design.

Content: the text, pictures, sound, and video that the Web site contains.

Community: the ways that the site enables userto-user communication.

Customization: the sites ability to tailor itself to different users or to allow users to personalize the site.

Communication: the ways the site enables site-touser, user-to-site, or two-way communication.
Connection: the degree that the site is linked to other sites.

Commerce: the sites capabilities to enable commercial transactions (Kotler \& Gary, 2005).

2.8 Empirical Review - Marketing, as well as different e-marketing forms - Business to Business Marketing (B2B), Business to Consumer Marketing (B2C) and Business to Government Marketing (B2G). There are numerous factors that are considered as prerequisites for using e-marketing in a company. For example, Peštek and Čičić mention the existence of a clearly defined strategy at a company level, the existence of the marketing function within the company, the domination of the marketing function in the development, implementation and monitoring of e-marketing results, and the existence of a database and building customer relations (Peštek and Čičić, 2010). When it comes to the implementation of e-marketing in tourism and hospitality it can be said that the acceptance of emarketing is determined by several factors such as owner skills, the available resources of an organization, the organization's organizational culture, emarketing adoption cost, size of the organization, ease of use, compatibility, competitive pressures, government influence, market trends, national infrastructure, and cultural orientation towards emarketing by the organization's customers (Lonelyplanet, 2011). Also, there exist numerous obstacles to e-marketing adoption. Dlodlo and Dhurup examined the relevant barriers contributing to the nonadoption of e-marketing practices by small and medium enterprises and found that they include technology incompatibility with target markets, lack of knowledge, stakeholder un-readiness, technology disorientation and technology perception (Dlodlo \& Dhurup, 2010).

\subsubsection{Empirical Research- example of South} Africa Hotels - The hotel industry is very developed in South Africa. To be competitive in the tourism and hospitality market, attract more guests and achieve a high level of customer satisfaction, hotels need to use information and communication technology (ICT). A considerable portion of the literature has emphasized the Impact of internet marketing on the performance of businesses indifferent countries (David et al., 1990). However, there is very little published literature on the impact of Internet marketing on the hotel and lodging sector in South Africa. Past research on Internet marketing in South 
Africa concentrated on the utilisation or the role of ecommerce or the Internet in tourism as a whole (Miller and Doyle, 1987). As a result, there is no clear picture of the state of Internet marketing adoption and its impact within the South African hospitality industry. (WTI, 2008) commented that previous studies on Information Communication Technologies in South Africa have often limited themselves to the role of ICT per se, and failed to capture the critical role and complexity of the utilization of ICT as a determining factor in shaping the impact on customers. An increase which is greater than $3 \%$ shows that internet marketing experience significantly moderates the relationship between Internet marketing usage and business profitability (Owen, Bhris, 2015).

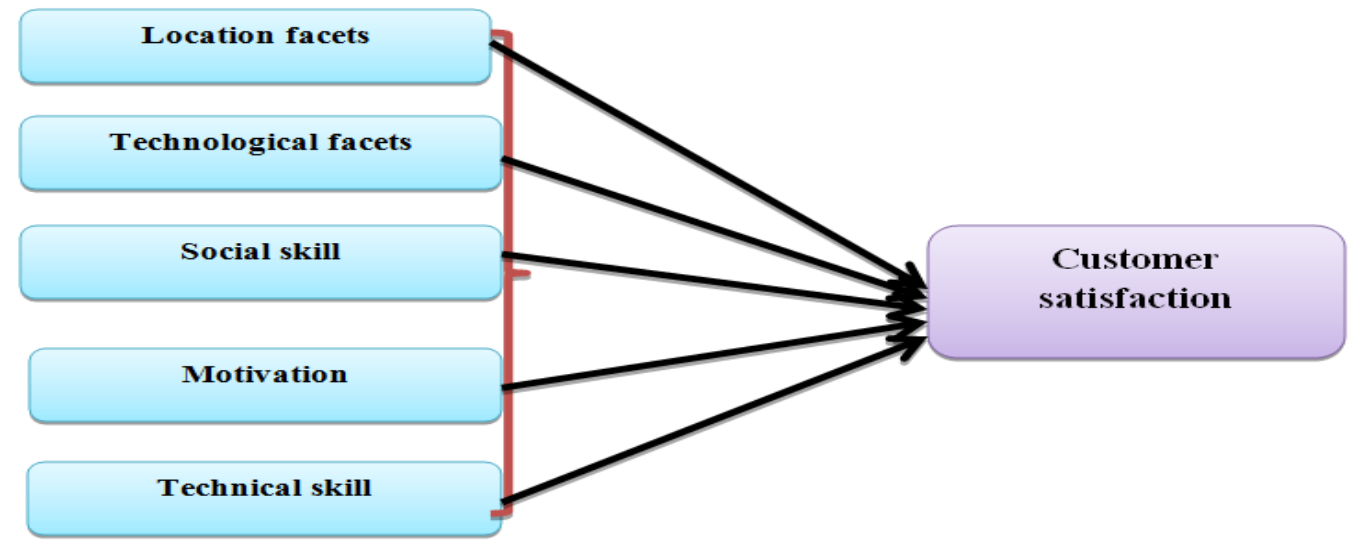

Fig 1: Conceptual frame work of the study.

\section{METHODOLOGY:}

3.1 Research Approach - There are two approaches for conducting a research; qualitative and quantitative approaches. Qualitative deals more with theoretical analysis of data, but does not pay more attention to the quantities of samples and data. On the other hand, the quantitative approach lays more emphasis on sample variables and their relationship on the overall Performance. The research was used both quantitative and qualitative data analysis. The researcher was used both primary and secondary data gathering techniques.

3.2 Research Design - A research design is the arrangement of conditions for collection and analysis of data in a manner that aims to combine relevance to the research purpose with economy in procedure. In fact, the research design is the conceptual structure within which research is conducted; it constitutes the blueprint for the collection, measurement and analysis of data. As such the design includes an outline of what the researcher will do from writing the hypo research and its operational implications to the final analysis of data. To do so the researcher preferred to go with the descriptive and explanatory research design because this research designs uses a set of scientific methods and procedures to collect raw data and create data structures that describe the existing characteristics of UniversePG I www.universepg.com a defined target population or market structure. Moreover descriptive research studies are those studies which are concerned with describing the characteristics of a particular individual, or of a group, whereas diagnostic research studies determine the frequency with which something occurs or its association with something else (Kothari, 2004).

3.3. Sampling Design - Survey can only be truly valuable when it's reliable and representative for the population to be studied however determining the ideal sample size one of the major tasks to be done. After all, a sample that is too big will lead to the waste of precious resources such as time and money, while a sample that is too small will not allow gaining reliable insights. There are two measures that affect the accurateness of the data. First there is the margin of error (is the positive and negative deviation from survey results).

In this research the deviation between the opinion of "effect of e-marketing on four star hotels" with margin of error $5 \%$, the researcher sure that between $85 \%(90 \%-5 \%)$ and $95 \%(90 \%+5)$ of the entire population responds how e-marketing affect their hospitality. Second there is the confidence level (how often the percentage of the population actually lays within the boundaries of the margin of error). 
3.3.1 Population - In this student research from standard four star hotels. The total target population are 750 consisted of Marke-ting Managers and customer of respective hotels who are recorded as loyal customers).

\subsubsection{Sample size and Sampling Technique -} Because of shortage of resources the researcher found difficult to deal with. Hence appropriate sample sizes were drawn. There are various Techniques for calculating the required sample size. According to the research Advisors in USA, 2016 construct a table that suggests the optimal sample size given population size, specific margin of error and a desired confidence interval. The table below presents the results of one set of these calculations used to determine the appropriate sample size for this study (confidence levels 95\% Margin of Error $=5 \%$ ), to use these values, determine the size of the population down the left most column (use the next highest value if the exact population size is not listed). The value in the next column is the sample size that is required to generate a margin of error of $\pm 5 \%$ for any population proportion.

\section{Required Sample Size}

\begin{tabular}{|c|c|c|c|c|}
\hline Population size & & \multicolumn{2}{|c|}{ Confidence =95\% } & \\
\hline & & \multicolumn{2}{|c|}{ Margin of error } & $1.0 \%$ \\
\hline & $5 \%$ & $3.5 \%$ & $2.5 \%$ & 10 \\
\hline 10 & 10 & 10 & 10 & 99 \\
\hline 100 & 80 & 89 & 94 & 148 \\
\hline 150 & 108 & 126 & 137 & 291 \\
\hline 300 & 169 & 217 & 251 & 384 \\
\hline 400 & 196 & 265 & 318 & 565 \\
\hline 600 & 234 & 340 & 432 & 653 \\
\hline 700 & 248 & 370 & 481 & 739 \\
\hline 800 & 260 & 396 & 526 & 906 \\
\hline 1000 & 278 & 440 & 606 & 9512 \\
\hline $1,000,000$ & 384 & 783 & 1534 & \\
\hline
\end{tabular}

Considering the above suggestions and the researcher population size of 750 to be studied and the sample size of 260 were drawn. In order to gain respondents opinion from customers, structured questioners distributed to 260 extracted samples. Whereas because number of hotel marketing managers where counted as 14 through physical observation in 14 four star hotels found in the study area, each have one marketing manager in the process. Hence Semi-structured questionnaires were asked to gather demographic and response rates of selected questions.

3.4 Sources of Data Collection - Here the research will use both primary and secondary data collection instruments. Questionnaire will be used for collecting primary data from the target population.

3.4.1 Primary Source - Data that have been observed, experienced or recorded close to the event are the nearest one can get to the truth, and are called primary data. There are many ways of collecting and recording primary data. Among them the researcher

UniversePG I www.universepg.com used questionnaire for the purpose of collecting primary data.

3.4.2 Secondary Source - Secondary data means data that are already available i.e., they refer to the data which have already been collected and analyzed by someone else. When the researcher utilizes secondary data, then he has to look into various sources from where he can obtain them. In this case he is certainly not confronted with the problems that are usually associated with the collection of original data (Kothari, 2004). Accordingly the researcher of this study used Addis Ababa hotel and Tourism report in order to obtain the required secondary data for study (Islam, 2020; Rahman and Rahman, 2020).

3.5 Instrument of Data Collection - In this study structured questionnaire was used since the aim of the study is to assess the effect of electronic marketing on customer satisfaction and how it is related to customer satisfaction. A survey questionnaire was distributed to hoteliers of four-star hotels in Addis Ababa. The structured questionnaires were tested before use to the main research analysis. 
3.6 Method of Data Analysis - Statistical Package for Social Sciences (SPSS) will be used for data analysis because of its capacity to analyze quantitative/numerical data, which the research incorporated the researcher will employ correlation analysis because correlation is primarily Concerned with finding out whether a relationship exists and with determining its magnitude and direction. When two variables vary together, such as loneliness and depression, they are said to be correlated. Accordingly, correlation studies are attempts to find the extent to which two or more variables are related. Typically, in a correlation study, no variables are manipulated as in an experiment the researcher measures naturally occurring events, behaviors, or personality characteristics and then determines if the measured scores vary. Therefore this is the best way to analyze the relationship of the dependent and independent variables. Correlation is used to analyze the cause and effect relationship between independent and dependent variables and is used to see the effect between the facets and the end result and viceversa which in this scenario are e. marketing hotels market development respectively.

3.6.1 Correlation Analysis - To quantitatively express the extent to which two variables are related, it is necessary to calculate a correlation coefficient. Correlation and regression analysis are related in the sense that both deal with relationships and effect among variables. The correlation coefficient is a measure of linear association between two variables. Values of the correlation coefficient are always between -1 and +1 . A correlation coefficient of +1 indicates that two variables are perfectly related in a positive linear sense; a correlation coefficient of -1 indicates that two variables are perfectly related in a negative linear sense, and a correlation Coefficient of 0 indicates that there is no linear relationship between the two variables. For simple linear regression, the sample correlation coefficient is the square root of the coefficient of determination, with the sign of the correlation coefficient being the same as the sign of b1, the coefficient of $\mathrm{x} 1$ in the estimated regression equation. Neither regression nor correlation analyses can be interpreted as establishing cause-and effect relationships. They can indicate only how or to what extent variables are associated with each other. The correlation coefficient measures only the degree of linear association between two variables. Any conclusions about a cause-and-effect UniversePG I www.universepg.com relationship must be based on the judgment of the analyst (www.encyclopediabritannica.com).

\subsubsection{Interpretation of Correlation Analysis -}

When comparing the correlation between two items, one item is called the "dependent" item and the other the "independent" item. The goal is to see if a change in the independent item (which is usually an indicator) will result in a change in the dependent item (usually a security's price). A coefficient of +1.0 , a "perfect positive correlation," means that changes in the independent item will result in an identical change in the dependent item (e.g., a change in the indicator will result in an identical change in the security's price).

A low correlation coefficient (e.g., less than \pm 0.10 ) suggests that the relationship between two items is weak or non-existent. A high correlation coefficient (i.e., closer to plus or minus one) indicates that the dependent variable (e.g., the security's price) will usually change when the independent variable (e.g., an indicator) changes. When comparing the correlation between an indicator and a security's price, a high positive coefficient (e.g., move then +0.70 ) tells you that a change in the indicator will usually predict a change in the security's price. A high negative correlation (e.g., less than -0.70) tells you that when the indicator changes, the security's price will usually move in the opposite direction. Remember, a low (e.g., close to zero) coefficient indicates that the relationship between the security's price and the indicator is not significant. Correlation analysis is also valuable in gauging the relationship between two securities. Often, one security's price "leads" or predicts the price of another security. For example, the correlation coefficient of gold versus the dollar shows a strong negative relationship. This means that an increase in the dollar usually predicts a decrease in the price of gold (www.metastock.com).

3.6.3 Pilot Testing - Pre-testing is the process of conducting a simulated administration of a design Questionnaire to a small representative group of respondents. It is an important step in the development of a questionnaire because it sheds light on possible improvement of the questionnaire's wording, structure and format. On this research pretesting was made amongst four-star hotels. From the pre-test survey it was noted that rephrasing of some words was necessary and was done accordingly. 
3.7 Measurement of Reliability - The scale of the model used were tested and found to be acceptable. That is reliable scale was found for cronbach alpha of constructs greater than 0.70 revealing satisfactory as all items are developed based on theories and literatures.

3.8 Validity Test - Establishing the validity of the scores in a survey helps to identify whether an instrument might be a good one to use in survey research (Creswell, 2009). Before using the questionnaire for the study it is always advisable to conduct pilot study or pilot survey for testing the questionnaires. In a big enquiry the significance of pilot survey is felt very much. Pilot survey is in fact the replica and rehearsal of the main survey. Such a survey, being conducted by experts, brings to the light the weaknesses (if any) of the questionnaires and also of the survey techniques. From the experience gained in this way, improvement can be effected (Kothari, 2004). In order to keep the validity of the instrument the researcher based previously developed questionnaires with some modifications to comply with the current study as well as conducted a pilot test on the questionnaires that developed for the study. An opinion also asked from hotel experts to look the questionnaires from the hotel side.
3.9 Ethical consideration - The researcher has already obtained consent of the four star hotels for the study; employees who completed the questionnaire has been informed about the purpose of data collection analysis and the covenant to maintain anonymity of their responses. The respondents are randomly selected from this data base authorized access was obtained from the relevant department. Letter of invitation was sent to respondent to check their willingness to participate in the research on voluntary basis. The questionnaire was clear about the voluntary participation. The research is purely for academic purpose and as a result of this the researcher was not reveal or use any of the confidential information or the business secretes of the hotels for another purpose.

\section{RESULTS AND DISCUSSION:}

4.1 Data screening and data cleaning - The total number of questionnaires distributed were 260 out of these 241 questionnaires was returned, yielding 92.7 percent response rate. However, 19 questionnaires were not completed properly as a result the number of questionnaires for data analysis was 241 .

Table 1: Distribution of sample size and response rate of questionnaires administered.

\begin{tabular}{|l|l|l|l|l|}
\hline \multicolumn{1}{|c|}{ Name of hotel } & $\begin{array}{c}\text { Number of } \\
\text { distribution }\end{array}$ & $\begin{array}{c}\text { Correctly filled and } \\
\text { returned questionnaires }\end{array}$ & $\begin{array}{c}\text { Not correctly } \\
\text { filled questionnaires }\end{array}$ & $\begin{array}{l}\text { Non returned } \\
\text { questionnaires }\end{array}$ \\
\hline Harmony Hotel & 20 & 19 & - & 1 \\
\hline Intercontinental Hotel & 20 & 18 & -- & 2 \\
\hline $\begin{array}{l}\text { Jupiter int. Hotel } \\
\text { (kazanchis) }\end{array}$ & 18 & 15 & - & 3 \\
\hline Jupiter Int. Hotel (Bole) & 18 & 18 & - & \\
\hline Momona Hotel & 18 & 18 & - & \\
\hline Nazrahotel & 18 & 16 & - & \\
\hline Nexus hotel & 18 & 18 & - & \\
\hline Saromaria hotel & 18 & 18 & - & 5 \\
\hline $\begin{array}{l}\text { Sarem International } \\
\text { Hotel }\end{array}$ & 20 & 15 & - & 1 \\
\hline $\begin{array}{l}\text { Tegen Guest } \\
\text { Accommodation Hotel }\end{array}$ & 18 & 17 & - & \\
\hline Washington hotel & 18 & 18 & - & \\
\hline Debredamo hotel & 18 & 18 & - & 5 \\
\hline Dreamliner Hotel & 18 & 18 & - & 19 \\
\hline Friendship hotel & 20 & 15 & - & \\
\hline Total & 260 & 241 & & \\
\hline
\end{tabular}


4.2 Reliability Test - The Reliability Statistics show that the scale exhibits a high degree of reliability. A Cronbach's Alpha coefficient of 0.70 is a commonly suggested threshold of reliability test. The researcher distributed 30 questionnaires as a pilot test.

4.3 Reliability Test all variable - This study uses cronbach's alpha to measure the reliability or to assess the internal consistency of the research instrument. As (Zikmund \& Carr, 2010) suggests that scale with 0.60 Alpha coefficients and above are considered acceptable As shown in Table 1 the Cronbach"s Alpha coefficients for service quality items ranges from 0.794 to 0.857 , these are greater than the minimum value. And the overall" Cronbach's alpha coefficient for all items is 0.826 . Therefore, the scales used in this study demonstrate high reliability as well as it indicates the acceptability of the scale for further analysis.

Table 2: Result of Reliability Statistics.

\begin{tabular}{|l|c|c|}
\hline & N of Items & Cronbach's Alpha \\
\hline Location facet & 9 & .801 \\
\hline Technology facet & 5 & .741 \\
\hline
\end{tabular}

\begin{tabular}{|l|c|c|}
\hline Social skill & 4 & .660 \\
\hline Motivation & 4 & .669 \\
\hline Technical skill & 5 & .748 \\
\hline Customer satisfaction & 4 & .774 \\
\hline Over all reliability & 31 & .917 \\
\hline
\end{tabular}

Table 3: Reliability test for all variables Reliability Statistics.

\begin{tabular}{|c|c|}
\hline Cronbach's Alpha & N of Items \\
\hline .917 & 31 \\
\hline
\end{tabular}

With a minimum value of 0.660 and 0.669 , the Cronbach's Alpha coefficients of all variables lie well above the commonly suggested threshold of 0.70 (Table 2). All variables together gave a value of 0.917 Cronbach's Alpha coefficients. So, in general all items of the variables are reliable (Table 3).

Normality Test - Normality of distribution can be tested by using histogram with a normal curve. In general the Fig 1 below shows that the variables are normally distributed for customer satisfaction

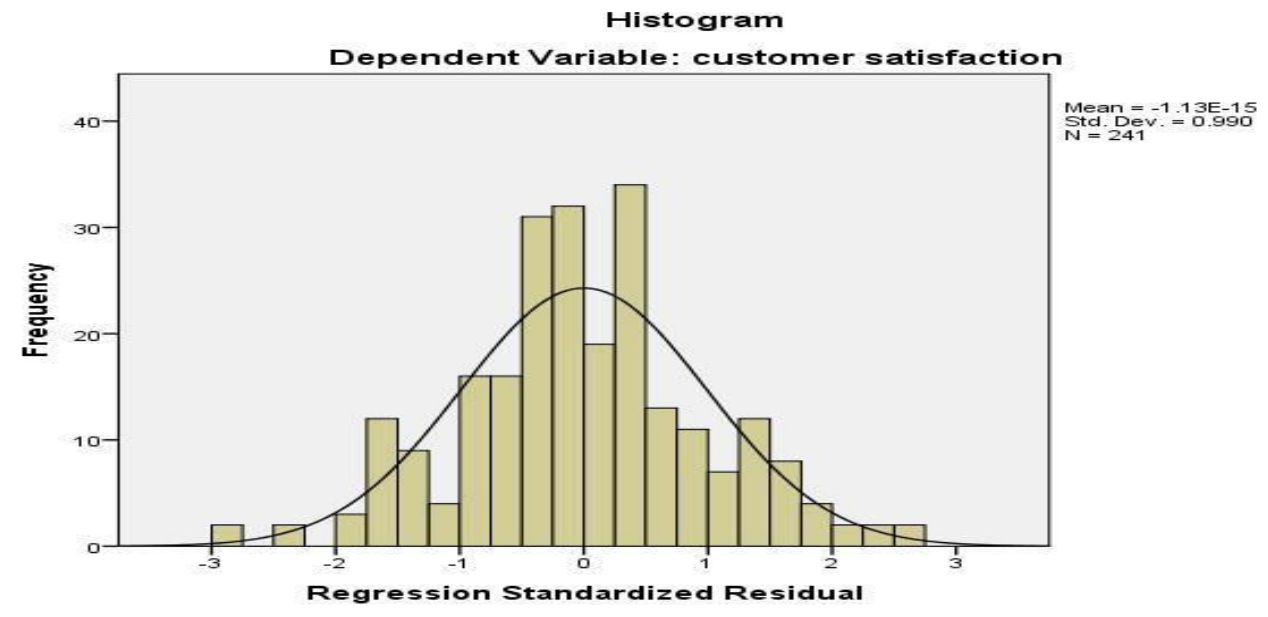

Fig 2: Normal Distribution Curve.

Table 4: Skewness and Kurtosis (Descriptive Statistics).

\begin{tabular}{|l|c|c|c|c|c|c|c|}
\hline & N & Mean & Std. Deviation & \multicolumn{2}{|c|}{ Skewness } & \multicolumn{2}{c|}{ Kurtosis } \\
\cline { 2 - 8 } & Statistic & Statistic & Statistic & Statistic & Std. Error & Statistic & Std. Error \\
\hline Location facet & 241 & 3.54 & .651 & -.188 & .157 & -.057 & .312 \\
Technology facet & 241 & 3.33 & .736 & .096 & .157 & -.454 & .312 \\
Social skill & 241 & 3.34 & .699 & .018 & .157 & -.398 & .312 \\
Motivation & 241 & 3.49 & .720 & -.347 & .157 & -.082 & .312 \\
Technical skill & 241 & 3.45 & .685 & -.277 & .157 & -.418 & .312 \\
Customer satisfaction & 241 & 3.57 & .729 & -.675 & .157 & -.045 & .312 \\
Valid N (list wise) & 241 & & & & & & \\
\hline
\end{tabular}


If skewness is equal to 0, the data are perfectly symmetrical. But a skewness of exactly zero is quite unlikely for real-world data. As (Field, 2005) put a generally acceptable range for skewness and kurtosis for further analyses is between the ranges of \pm 2.0 . Others extend the range of kurtosis up to \pm 3.0 . Kurtosis statistics is used to measure the peakedness of the distribution. The reference standard is a normal distribution, which has a kurtosis of 3 and the lower bound is -3 . The Table 4 shows the skewness and kurtosis statistics of the distribution.

The above table indicates that all variables are under the acceptable range of skewness which is between the ranges of \pm 2 . For the two variables motivation and technical skill their kurtosis statistics shows a leptokurtic kind but other variables are under the acceptable range. The overall distribution is reflected as normal.

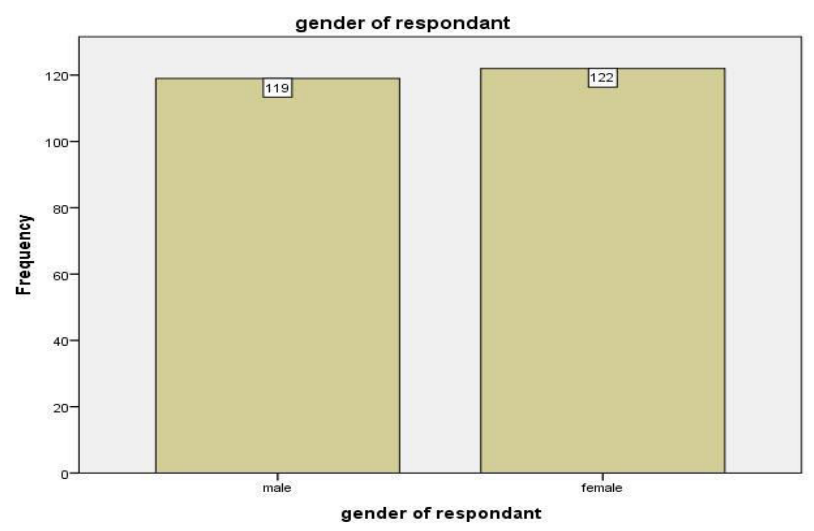

Fig 3: gender of respondent.

The Fig 3 shows the ratio of male to female is almost 1:1 which indicates both male and female groups are equally use hotel services in the study area.

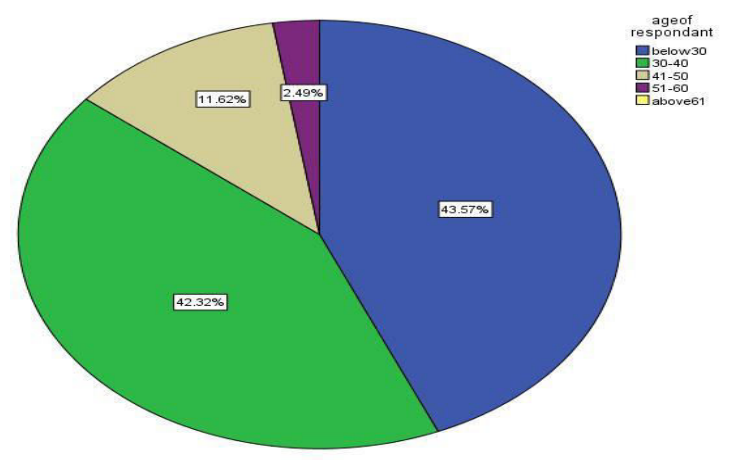

Fig 4: Age of respondent.

Fig 4 above shows that the valid age of respon-dents of structured questionnaire prepared for hotel customer. The summary figure indicated that the majority of the respondents are It indicates that young populations of the society with (43.57\%) below age of 30 Other major age group is between 31-40 which have a share of 42.32 percent.

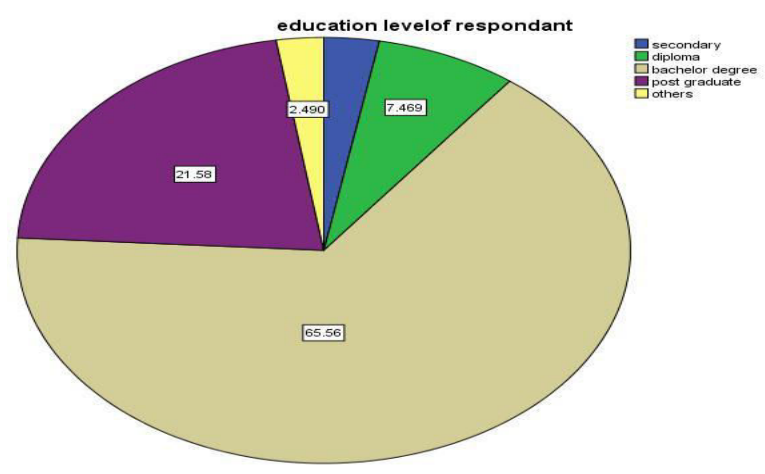

Fig 5: Academic Qualification.

Fig 5 Shows most of the respondents are first degree holders which constitutes 65.56 Percent of the total respondents. As indicated above, most of the respondents are young so, most young population which uses hotels has first degree. Another significant percentage is 21.6 which represent master's holders. Respondents with secondary and below secondary are 5.4 percent of the total respondents. The rest 7.5 percent of the respondents are diploma holders.

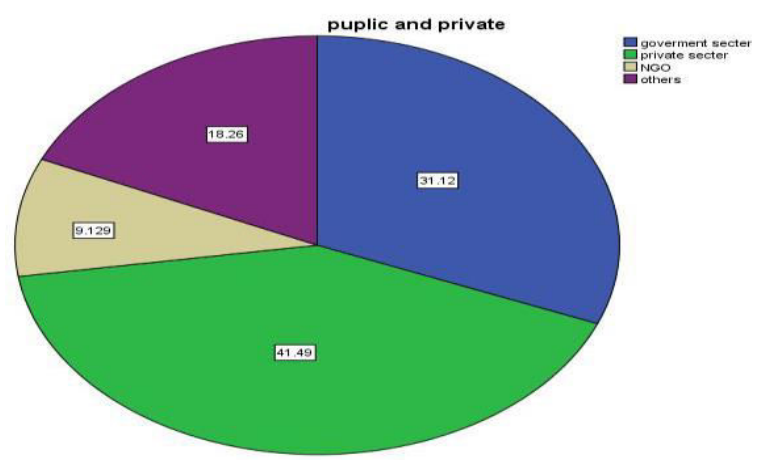

Fig 6: Sector of the respondent.

Fig 6 shows that 41.5 percent of respondents are a customer of private sector which is outside the government sector and 31.1 percent of respondents are comes from government sector the rest 9.1 percent of respondents are a customer of NGO and 18.3 percent are other customers of in four star hotels.

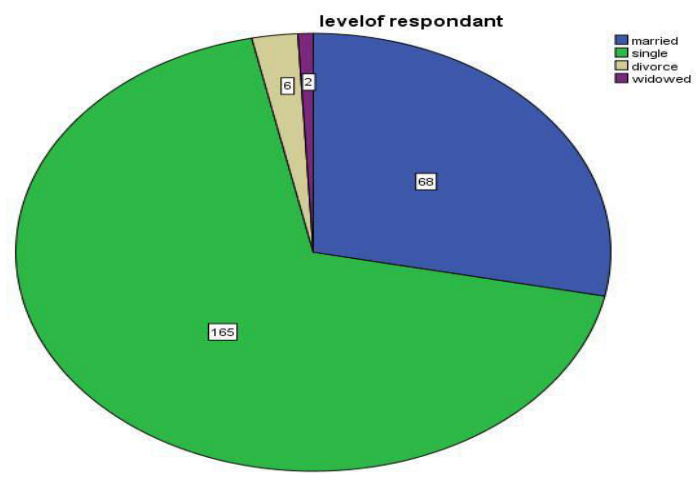

Fig 7: marital status of the respondent. 
The below Fig 5 show the marital status of the respondent from respondents of view, married accounted for $68(28.2 \%)$, Single accounted for 165(68.5), divorce accounted for 6(2.5) and respondents who are widowed accounted for 2(0.8) are stated in the above figure.

Table 5: Summary of Demographic Variables.

\begin{tabular}{||l|c|c|}
\hline $\begin{array}{c}\text { Description of } \\
\text { response }\end{array}$ & Response & \\
\hline A) Gender & Number & Percentage \\
\hline Female & 122 & 50.6 \\
\hline Male & 119 & 49.4 \\
\hline Total & 241 & 100.0 \\
\hline B) Age & & \\
\hline Below 30 & 105 & 43.6 \\
\hline $31-40$ & 102 & 42.3 \\
\hline $41-50$ & 28 & 11.6 \\
\hline $51-60$ & 6 & 2.5 \\
\hline Above 60 & - & - \\
\hline Total & 241 & 100.0 \\
\hline
\end{tabular}

\begin{tabular}{||l|c|c|}
\hline C) Qualification & & \\
\hline Secondary & 7 & 2.9 \\
\hline Diploma & 18 & 7.5 \\
\hline Bachelor Degree & 158 & 65.6 \\
\hline Post graduate & 52 & 21.6 \\
\hline Other & 6 & 2.5 \\
\hline Total & 241 & 100.0 \\
\hline D) Sectors & & \\
\hline $\begin{array}{l}\text { Government } \\
\text { sector }\end{array}$ & 75 & 31.1 \\
\hline Private sector & 100 & 41.5 \\
\hline NGO & 22 & 9.1 \\
\hline Others & 44 & 18.3 \\
\hline Total & 241 & 100.0 \\
\hline E) Marital status & & \\
\hline Marred & 68 & 28.2 \\
\hline Single & 165 & 68.5 \\
\hline Divorced & 6 & 2.5 \\
\hline Widowed & 2 & 0.8 \\
\hline Total & 241 & 100.0 \\
\hline Total & 241 & 100.0 \\
\hline
\end{tabular}

\subsection{Hotel marketing Managers structured and Semi-structured Interview Demographic Profile}

Table 6: Distribution of respondents by respondent of Gender.

\begin{tabular}{|c|c|c|c|c|c|}
\hline & & Frequency & Percent & Valid Percent & Cumulative Percent \\
\hline & Male & 4 & 36.4 & 36.4 & 36.4 \\
\hline Valid & Female & 7 & 63.6 & 63.6 & 100.0 \\
\hline & Total & 11 & 100.0 & 100.0 & \\
\hline
\end{tabular}

The summary of 11 Hotel Managers with gender shows that males are $4(36.4 \%)$ and females accounted for 7(63.6\%). The distribution of sample respondents by gender given in Table 6 above.

4.4.1 Age of Respondents - Table 7 below shows that the valid age of respondents of structured questionnaire prepared for hotel managers. The summary table indicated that the majority of the respondents are in the age between 31-40 with 63.6 $\%$ and only $4(36.4 \%)$ are below age of 30 .

4.4.2 Sector and Position of respondents - All of the $11(100 \%)$ respondents business sector make straight with private sectors since no government owned four star hotels found in the city. Other summary table also shows that all of respondents are marketing managers in their position. The summary table shows such distribution found in Table 8 and 9 below.

UniversePG I www.universepg.com
4.4.3 Marital Status of the respondent - From respondents of view, married accounted for 5 $(45.5 \%)$ and respondents who are single accounted for 6 (54.5) in Table 10 below.

Table 11 below shows almost half of marketing managers are education qualification of Post Graduate with $45.5 \%$ and the remaining 6 (54.5\%) are holders of BA degree.

4.5 Multi-collinearity - In multiple regression analysis, the regression coefficients (viz., b1 b2) become less reliable as the degree of correlation between the independent variables (viz., X1, X2) increases. If there is a high degree of correlation between independent variables, we have a problem of what is commonly described as the problem of multi-collinearity. 
Table 7: Distribution of respondents by Age.

\begin{tabular}{|c|c|c|c|c|c|}
\hline & & Frequency & Percent & Valid Percent & Cumulative Percent \\
\hline & Below 30 & 4 & 36.4 & 36.4 & 36.4 \\
\hline Valid & $31-40$ & 7 & 63.6 & 63.6 & 100.0 \\
\hline & Total & 11 & 100.0 & 100.0 & \\
\hline
\end{tabular}

Table 8: Distribution of respondents by Sector of business (public and private).

\begin{tabular}{|c|l|c|c|c|c|}
\hline \multicolumn{2}{|c|}{} & Frequency & Percent & Valid Percent & Cumulative Percent \\
\hline Valid & Private & 11 & 100.0 & 100.0 & 100.0 \\
\hline
\end{tabular}

Table 9: Distribution of respondents by Position in the Hotel Position.

\begin{tabular}{|c|l|c|c|c|c|}
\hline \multicolumn{2}{|c|}{} & Frequency & Percent & Valid Percent & Cumulative Percent \\
\hline Valid & Private & 11 & 100.0 & 100.0 & 100.0 \\
\hline
\end{tabular}

Table 10: Distribution of respondents by marital status Married respondents.

\begin{tabular}{|l|c|c|c|c|c|}
\hline \multicolumn{2}{|c|}{} & Frequency & Percent & Valid Percent & Cumulative Percent \\
\hline Valid & Married & 5 & 45.5 & 45.5 & 45.5 \\
\hline & Single & 6 & 54.5 & 54.5 & 100.0 \\
\hline & Total & 11 & 100.0 & 100.0 & \\
\hline
\end{tabular}

Table 11: Distribution of respondents by level education.

\begin{tabular}{|c|c|c|c|c|c|}
\hline & & Frequency & Percent & Valid Percent & Cumulative Percent \\
\hline & BA Degree & 6 & 54.5 & 54.5 & 54.5 \\
\hline Valid & Post G & 5 & 45.5 & 45.5 & 100.0 \\
\hline & Total & 11 & 100.0 & 100.0 & \\
\hline
\end{tabular}

Fortunately, collinearity is relatively easy to detect by calculating the tolerance or VIF (Variance Inflation Factor). A tolerance of below 0.10 indicates that (multi) collinearity is a problem. The VIF is just the reciprocal value of the tolerance. Thus, VIF values above ten indicate collinearity issues. According to this measurement none of the variables tolerance level is below 0.10 and their VIF above ten. So, there is no a Multi-collinearity problem with the variable (Table 12).

Table 12 Collerity Statistics (Coefficients ${ }^{\mathrm{a}}$ ).

\begin{tabular}{|c|l|c|c|}
\hline \multirow{2}{*}{ Model } & & \multicolumn{2}{c|}{ Collinearity Statistics } \\
\hline & & Tolerance & VIF \\
\hline & Location facet & .573 & 1.745 \\
\hline & Technology facet & .591 & 1.693 \\
\hline 1 & Social skill & .548 & 1.825 \\
\hline & Motivation & .496 & 2.016 \\
\hline & Technical skill & .495 & 2.022 \\
\hline
\end{tabular}

a. Dependent Variable: customer satisfaction.
4.6 Correlation Analysis - Correlation analysis is one of the most widely used in research, it is often used to determine a relationship between two different variables, if so how significant or how strong the association between variables is. The correlation coefficient $r$ is statics used to measure the degree or strength of this type of relationship (Taylor, 1990). In this research the correlation analysis was performed to see the relationship between e. marketing and customer's satisfaction in four star hotels. Therefore, the correlation analysis will indicate the relationship between Location facet, Technological facet, Social skill, Motivation and Technical skill with customer satisfaction. To interpret the strengths of relationships between variables, the guidelines suggested by (Taylor, 1990), were followed. His classification of the correlation coefficient ( $r$ ) is as follows: $\leq 0.35$ is considered to represent low or weak correlation; $0.36-0.67$ is modest or moderate correlation; 0.68 0.89 is strong or high correlation and a correlation with $r$ coefficient $\geq 0.90$ is very high correlation. Again if the correlation result lies between -1 and 0 , the two variables are negatively related. However, 
the result is interpreted and discussed using this criterion in each dimensions.

4.7. Relationship between Location Facet and customer Satisfaction - The relationship between the two variables has moderate relationship at $\mathrm{r}=.482 * *$ the above Pearson correlation shows that location facets has significant impact on hotel customer satisfaction also association between location facets with hotels customer satisfaction with the value of $(\mathrm{r}=.482, \quad \mathrm{P}<0.01)$, these implies that customer satisfaction in the hotels e. marketing has significant and positive Correlation specifically with the location facets.

4.8 Relationship between Technological Facet and Customer Satisfaction - As shown in Table 13 attempted to clarify the correlation between the technological facets as independent variable and customer satisfaction as dependent variable. As it is already shown, the two variables have influence each other significantly and positively. In addition, the $r=397 * *$ value indicates that technological facets of the e. marketing maintains moderate Correlation with the customer satisfaction in the context of four star hotels.

4.9 Relationship between Social Skill and Customer satisfaction - As shown in Table 13 tried to explain, the relationship between the social skill as independent variable and the customer satisfaction as dependent variable. As it is already shown, the two variables have significantly positive relation-ships. This implies that, the two variables influence each other positively. In addition, the $\mathrm{r}=.477 * *$ value also implies that any change on social skill have a direct impact on customer satisfaction either positively or negatively.

Table 13 Multiple regression.
4.10 Relationship between Motivation and Customer Satisfaction - The relationship between motivation and customer's satisfaction shows that the correlation result of the two variables, motivation and customer satisfaction is $.635^{* *}$, this implies that the two variables are significant and positively related.

4.11 Relationship between Technical Skill and Customer Satisfaction - Technical skill was taken as independent variable and customer satisfaction as dependent variable. And the correlation result for this two variables is $.680^{* *}$, this implies the two variables are also significantly and positively related. In addition, the $r=.680 * *$ indicates that Technical skill maintains strong or high correlation relationship with the customer satisfaction in context of four star hotels.

4.12 Regression Analysis - Regression analysis is one of the most frequently used tools in market research. In its simplest form, regression analysis allows market researchers to analyze relationships between one independent and one dependent variable. In marketing applications, the dependent variable is usually the outcome we care about, while the independent variables are the instruments we have to achieve those outcomes with. It can also help make predictions.

4.13 Multiple regression analysis - To identify the electronic marketing that make the greatest contributions to overall customers satisfaction in four star hotels, multiple regression analyses were conducted with overall customers satisfaction as the dependent variable and the five variables are as the independent variables. The result has been shown below.

\begin{tabular}{|l|l|l|l|l|}
\hline Model & R & R Square & R Square & Std. Error of the Estimate \\
\hline 1 & $.734^{\mathrm{a}}$ & .539 & .529 & .500 \\
\hline
\end{tabular}

a. Predictors: (Constant), technical skill, technology facet, location facet, social skill, motivation.

b. dependent variable customer satisfaction.

Table 14 ANOVA for Customer Satisfaction

\begin{tabular}{|l|c|c|c|c|c|}
\hline \multicolumn{1}{|c|}{ Model } & Sum of Squares & Df & Mean Square & F & Sig. \\
\hline Regression & 68.684 & 5 & 13.737 & 54.864 & $.000^{\mathrm{b}}$ \\
\hline Residual & 58.839 & 235 & .250 & & \\
\hline Total & 127.523 & 240 & & & \\
\hline
\end{tabular}

a. Dependent Variable: customer satisfaction.

b. Predictors: (Constant), technical skill, technology facet, location facet, social skill, motivation.

UniversePG I www.universepg.com 
$\mathrm{R}$, the multiple regression coefficients, is the linear regression between the observed and modelpredicted values of the dependent variable. Its large value indicates the strength of the relationship. From the Table 13 above, R Square (0.529) the coefficient of determination shows that about .529 percent of the variation in overall service quality is explained by the model. Or which means .529 percent of the variance in customers satisfaction is influenced by the five variables that are Location facet, technological facet, social skill, motivation, technical skill. Similarly, ANOVA table provides similar information with the model summary on the ANOVA Table 14, overall significance/acceptability of the model from a statistical perspective can be determined. As the significance value of $F$ statistics shows a value (.000), which is less than $\mathrm{p}<0.05$ the model is significant, which means that the variation explained by the model is not due to chance. The interpretation of the sum of square column of the table is similar with the results of $\mathrm{R}$ square. It display information about how much of the variation in customers satisfaction is accounted by the predictor variables and how much is not. ANOVA test was also conducted as shown above.

Analysis: $\mathrm{F}$ value is 54.864 at significant level of 0.000 Coefficients'. The table below shows the constant, beta, and significance level of each variable. It indicates that except location facet, technological facet, and social skill the tow variables motivation and technical skill influence customer satisfaction significantly. As the constant and B values are known the model will be:

Cus Sat $=0.425+0.089$ Loc Fac + 0.093Tec Fac + $0-.008$ Soc sk+0.284Mot + 0.451Tec sk +0.05

Multiple regressions for customer satisfaction Coefficients.

\begin{tabular}{|c|c|c|c|c|c|c|}
\hline \multicolumn{2}{|l|}{ Model } & \multicolumn{2}{l|}{ Unstandardized Coefficients } & Standardized Coefficients & T & Sig. \\
\hline & & B & Std. Error & Beta & & \\
\hline & (Constant) & .425 & .209 & & 2.035 & .043 \\
\hline & Location facet & .089 & .066 & .079 & 1.355 & .177 \\
\hline & Technology facet & .093 & .057 & .094 & 1.625 & .105 \\
\hline 1 & social skill & -.008 & .062 & -.008 & -.136 & .892 \\
\hline & Motivation & .284 & .064 & .280 & 4.456 & .000 \\
\hline & technical skill & .451 & .067 & .424 & 6.734 & .000 \\
\hline
\end{tabular}

a. Dependent Variable: customer satisfaction.

b. Statistically significant $(\mathrm{p}>0.05)$.

\subsection{Hypo research Testing}

H1: Location facets have a positive and significant effect on customer satisfaction in four star hotels in Addis Ababa. The regression result of location facet with customer satisfaction shows that insignificant level of influence at 95 percent confidence interval with a sig. value of 0.177 . Because the significant $>0.05$. This result shows the rejection of the first hypo research.

H2: Technological facets have significant and positive effect on customer satisfaction in four star hotels in Addis Ababa. The regression result of technological facet with customer satisfaction shows that insignificant level of influence at 95 percent confidence interval with a sig. value of 0.105 .
Because the significant $>0.05$. This result shows the rejection of the second hypo research.

H3: There is a positive and significant effect between social skill and customer satisfaction in four star hotels in Addis Ababa. The regression result of social skill with customer satisfaction shows that insignificant level of influence at 95 percent confidence interval with a sig. value of 0.892 . Because the significant $>0.05$ this result shows the rejection of the third hypo research.

H4: Motivation positively and significantly effects customer satisfaction in four star hotels in Addis Ababa. The output of the regression analysis shows that motivation has a significant positive influence on customer satisfaction with a sig. value of 0.000 . A single unit change in motivation will affect 
customer satisfaction by 0.284 . Thus, the forth hypo research is supported.

H5: Technical skills have a positive and significant effect on customer satisfaction in four star hotels in Addis Ababa. The output of the regression analysis shows technical skill has a significant positive influence on customer satisfaction (sig.
$0.000)$. When reputation is changed by a single unit customer Satisfaction will be affected by 0.451 . This beta value is the highest among all variables so; we can say that technical skill is the highest influencer of customer satisfaction than the other variables. Due to this result, the fifth hypo research is supported.

Table 15 Descriptive Statistics all variable.

\begin{tabular}{|c|c|c|c|c|c|}
\hline & N & Minimum & Maximum & Mean & Std. Deviation \\
\hline Location facet & 241 & 2 & 5 & 3.54 & .651 \\
\hline Technology facet & 241 & 2 & 5 & 3.33 & .736 \\
\hline Social skill & 241 & 2 & 5 & 3.34 & .699 \\
\hline Technical skill & 241 & 2 & 5 & 3.45 & .720 \\
\hline Motivation & 241 & 2 & 5 & 3.49 & .729 \\
\hline Customer satisfaction & 241 & 2 & 5 & 3.57 & \\
\hline Valid N (list wise) & 241 & & & & \\
\hline
\end{tabular}

Table 16 Overall customer satisfaction (Descriptive Statistics).

\begin{tabular}{|c|c|c|c|c|c|}
\hline & $\mathbf{N}$ & Minimum & Maximum & Mean & Std. Deviation \\
\hline Overall customer & 241 & 2 & 5 & 3.57 & .729 \\
\hline Satisfaction & 241 & & & & \\
\hline
\end{tabular}

Table 17 Summary of Hypo research Test.

\begin{tabular}{|l|l|l|l|}
\hline Hypo research & Description & Analysis method & Remark \\
\hline H1 & $\begin{array}{c}\text { Location facets have a positive and significant effect on customer } \\
\text { satisfaction in four star hotels in Addis Ababa. }\end{array}$ & Regression & Rejected \\
\hline H2 & $\begin{array}{c}\text { H2: Technological facets have significant and positive effect on } \\
\text { customer satisfaction in four star hotels in Addis Ababa. } \\
\text { H3 }\end{array}$ & $\begin{array}{c}\text { Regression } \\
\text { customer satisfaction in four star hotels in Addis Ababa }\end{array}$ & Rejected \\
\hline H4 & $\begin{array}{r}\text { Motivation positively and significantly affects customer } \\
\text { satisfaction in four star hotels in Addis Ababa }\end{array}$ & Regression & Supported \\
\hline H5 & $\begin{array}{l}\text { Technical skills have a positive and significant effect on } \\
\text { customer satisfaction in four star hotels in Addis Ababa }\end{array}$ & Regression & Supported \\
\hline
\end{tabular}

According to Table 16 customers overall satisfaction has mean score of 3.57 which shows customers of four star hotels found in Addis Ababa, are satisfied with the hotels e. marketing services of the hotels.

4.15 Summary of Hypo research Test - The following table shows hypo research of the study, method used to test proposed hypo research and its outcome (Table 18).

\subsubsection{Frequency of Promoting on Internet -} When asked about how often sample hotels promote their company promotes through online, $54.5 \%$ of respondents said they promote every day using internet and the rest $45.5 \%$ promote weekly basis. The frequency of hotels marketing managers' responses shown on Table 18 below:

\subsubsection{Competitive Pressure to apply innovative} e-marketing service - From Table 20, $54.5 \%$ of respondents said competitive pressure much affect to apply innovative e-marketing practices and $36.4 \%$ said competitive pressure very much derive hotels to apply innovative e-marketing for customer satisfaction. Whereas only 1 respondent said very little affect to apply e-marketing. 
4.15.3 Top management discussion on competetor's strength and weakness in e-marketing When asked about to managements discuss competitors' strength and weakness in their emarketing, $54.5 \%$ said they strongly agree about the case and $27.3 \%$ of respondents neutral about the discussion undertaken in their hotels as shown in

Table 21.

Table 18: Frequency of hotel promotion using internet.

\begin{tabular}{|l|l|l|l|l|l|}
\hline & & Frequency & Percent & Valid Percent & Cumulative Percent \\
\hline & e. day & 6 & 54.5 & 54.5 & 54.5 \\
\hline Valid & e. week & 5 & 45.5 & 45.5 & 100.0 \\
\hline & Total & 11 & 100.0 & 100.0 & \\
\hline
\end{tabular}

Table 19: Distribution of objective of using e-marketing.

\begin{tabular}{|c|c|c|c|c|c|}
\hline & & Frequency & Percent & Valid Percent & Cumulative Percent \\
\hline & To expand & 9 & 81.8 & 81.8 & 81.8 \\
\hline & To reach & 1 & 9.1 & 9.1 & 90.9 \\
\hline Valid & & & & & 100.0 \\
\hline & Other & 1 & 9.1 & 9.1 & \\
\hline & Total & 11 & 100.0 & 100.0 & \\
\hline
\end{tabular}

Table 20: Frequency of applying innovative e-marketing.

\begin{tabular}{|c|c|c|c|c|c|}
\hline & & Frequency & Percent & Valid Percent & Cumulative Percent \\
\hline & very much & 4 & 36.4 & 36.4 & 36.4 \\
\hline & Much & 6 & 54.5 & 54.5 & 90.9 \\
\hline Valid & & & & & 100.0 \\
\hline & very little & 1 & 9.1 & 9.1 & \\
\hline & Total & 11 & 100.0 & 100.0 & \\
\hline
\end{tabular}

Table 21: Top Management discussion on competitors' e-marketing position.

\begin{tabular}{|c|c|c|c|c|c|}
\hline & & Frequency & Percent & Valid Percent & Cumulative Percent \\
\hline & strongly agree & 6 & 54.5 & 54.5 & 54.5 \\
\hline & Agree & 2 & 18.2 & 18.2 & 72.7 \\
\hline Valid & & & & & 100.0 \\
\hline & Neutral & 3 & 27.3 & 27.3 & \\
\hline & Total & 11 & 100.0 & 100.0 & \\
\hline
\end{tabular}

Generally from structured and semi-structured interview questionnaire filled by marketing managers of hotels, the last question regarding the general comment on opportunities and challenges of applying e-marketing, 9 of respondents said the overall network condition of the country mentioned as a challenge and 5 of them skipped without giving answer. On the other hand from 14 respondents of marketing managers 3 of them were not willing to
4.15.4 Objective of using e-marketing in four star hotels - As shown in Table 19 9(81.8\%) of hotel managers said they use e-marketing mostly to expand the market at international level. The remaining $2(9.1 \%$ each) respondents said emarketing to reach new customers and for other purposes. 
and technical skill with customer satisfaction are strong relationship. Location facet, technological facet, and social skill are insignificant and also rejected on the other hand the two of the variables (motivation and technical skill) have a significance, positive and also supported influence on customer satisfaction. From the whole variables technical skill has higher positive influence on customer satisfaction.

\section{CONCLUSION AND RECOMMEDATIONS:}

This study has the objective to examine the effect of electronic marketing on customer satisfaction, by taking location facet, technological facet, social skill, motivation and technical skill as independent variables and also taken overall customer satisfaction as a dependent variable so as to run different analysis and to answer basic research questions finally the conclusion stated as follow: According to the regression result, technical skill, motivation have significant and positive effect with overall customer satisfaction this supported by the result of (Lonelyplanet, 2011) in his study. Also location facet, technological facet and social skill variables have insignificant effect with overall customer satisfaction this finding supported by the result obtained by (Ahmed et al., 2013) in their study. The result of the regression analysis shows a positive effect between the two independent variables which is motivation and technical skill the dependent variable as the coefficient of independent variables carried positive signs. The relative importance of hotel electronic marketing factors to customer's overall satisfaction is determined by looking at the standardized beta coefficient. The factor which had the greatest impact on the overall customer satisfaction has been technical skill with a beta coefficient of 0.451 . This indicates technical skill explain 45.1 percent of variance in hotels customers rating of overall customer satisfaction on the hotels e. marketing. Nevertheless, the researcher was able to conclude that the management perception toward e. marketing is in significance and emphasizes more on the location facet, technological facet and social skill variables. For the most part, managers overestimate their e. marketing variable as they compare to other.

The study confirmed that the two electronic marketing variables which are motivation and technical skill are positively significant with overall UniversePG I www.universepg.com customer satisfaction; hence the hotels should give strong emphasis to all e. marketing dimensions in maintaining and improving the e market of the hotel. Up on this, the following recommendations are forwarded for those who engaged in hotel service sector by the researcher. In this study among these e. marketing variables, technical skill shows the highest significance positives effect with customer satisfaction, therefore it is advised to pay attention by the hoteliers because the technical skill that found on the e. market should give relevant information starting from hotels service up to the area where the hotel located and also about new events that takes place, as well as other technical skill which makes the hotels different from other, though the hotel should give special attention to this variable because it determine customer satisfaction. On the other hand from the beta value we have seen that technical skill was the highest influencer of customers' satisfaction. In addition to the researcher's observation the e marketing of the hotel should be up to date and also informs customers about new events and daily information through e. marketing base.

\section{Further Research Implications}

This study has been limited on electronic marketing by participating four star hotels. The proposed model could be modified to allow measurement of customer perception across different sectors of hospitality such as restaurants, tour operators, car rent services, travel agencies and so on. This would enable a direct comparison of results across different types of supply-side stakeholders.

\section{ACKNOWLEDGEMENTS:}

Above all I would like to thank the Almighty God for the strength he gave in all spot of life. Along with, I would like to forward my sincere thanks and appreciation to my family for the support and tolerance they gave me at a time of conducting this research. This study would be far from success if it were not supported by all of you. My deepest appreciation goes to all staffs of the four star hotels in Addis Ababa, Ethiopia for their cooperation and permission for distributing questionnaires for the customers who are served by them. I also thanks, people who helped me in gathering primary data with genuineness support. Last but not least, my thanks go to all those who I haven't mentioned, my colleagues and all of my friends. 


\section{CONFLICTS OF INTEREST:}

There is no conflict of interest regarding the publication of this manuscript.

\section{REFERENCES:}

1. Ahmed, M., Said, A., \& Azizan, N. (2013), Factors Affecting E-commerce Adoption among Hotel Industry in Libya; Proceeding of the International Conference on Social Science Research, ICSSR; Penang, Malaysia. Pp 1341-1350. https://doi.org/10.13140/RG.2.1.1315.5048

2. American Marketing Association, (2008). The American Marketing Association Releases New Definition for Marketing, Chicago, IL (PRWEB) January 14.

https://www.prweb.com/releases/definition/for_ma rketing/prweb621321.htm

3. Andrlić, B. (2007) "Primjena e-marketinga u turizmu”, Poslovna izvrsnost, 1(2), p. 85-97.

4. Barsky (1992), A Strategy for Customer Satisfaction, Sage journals, 33(5), 32-40. https://doi.org/10.1177/004728759303100429

5. Barsky and Huxley (1992), customer satisfaction measurement in hotel industry: content analysis study, faculty of tourism and hospitality management, Croatia.

6. Chris Chatwin (University of Sussex; UK) (2013). Electronic Marketing [internet] Addis Ababa. http://www.wikipedia.org/

7. Cox, B., \& Koelzer, W., 2004, Internet marketing in hospitality; Pearson Prentice Hall. Pp 320 pages.

https://www.amazon.com/Internet-Marketing-Ho spitality-Barbara-Cox/dp/0130984752

8. Creswell, W. (2009). Research design: Qualitative, Quantitative and Mixed methods approaches. Los Angeles: Sage Publications, Inc. https://psycnet.apa.org/record/2008-13604-000

9. Dahlen, Micael (2010), Marketing Communications: A Brand Narrative Approach. Chichester, West Sussex UK: John Wiley \& Sons Ltd. Pp 36.

https://www.wiley.com/en-us/Marketing+Commu nications $\% 3 \mathrm{~A}+\mathrm{A}+$ Brand+Narrative + Approach-p9780470319925

10. David, C., Gilbert, J., Pallab, P., and Siana, J. (1990), Approaches by Hotels to the use of the Internet as a relationship marketing tool; Journal of marketing practice: applied marketing science, 5(1), 21-38.
11. Dlodlo, N. \& Dhurup, M. (2010), barriers to emarketing Adoption among Small and Medium Enterprises (SMEs) in The VAAL Triangle; Faculty of Management. Acta Commercii, 10(1), 164-180. https://doi.org/10.4102/ac.v10i1.126

12. Field, A., 2005. Regression. In: s.l.:s.n., pp. 143217.

13. Friendship International Hotel (2013), [internet] Addis Ababa, Available at http://www.friendshiphotel.com/

14. Gilbert \& Horsnell (1998), customer satisfaction measurement practices in hotels. Some evidence from Albania, research gate.

15. Grybniak (2014), barriers to e-marketing adoption in the hotel industry in Ethiopia.

16. Hensens, Struwng \& Dayan (2010), "Guest review criteria on trip advisor compared to conventional hotel-rating systems to assess hotel quality. Eurochire, 2010.

17. Heskett et al. (1997), the service profit chain: how leading companies' link profit and growth to loyalty, satisfaction, and value, Harvard business school, New York: Free Press.

https://www.hbs.edu/faculty/Pages/item.aspx?num $=284$

18. Hossain MA, Suchana JJ, and Avi MAR. (2020). Promoting Bangladesh tourism through the internet: theoretical perspectives and empirical evidence, Can. J. Bus. Inf. Stud., 2(5), 87-95. https://doi.org/10.34104/cjbis.020.087095

19. Hossain MM. (2020). Influential factors of tourists' satisfaction in Bangladesh: evidence from selected tourism destinations at Cumilla region, Can. J. Bus. Inf. Stud., 2(4), 75-86. https://doi.org/10.34104/cjbis.020.075086

20. Iacovou C (2004). Internet Marketing and Its Impact on the Four Star Hotels in Cyprus; a Research Study Submitted in Partial Fulfillment of the Requirements for the Master of Science Degree. International Journal of Contemporary Hospitality Management, 23(4), p. 552-564.

21. Islam MJ, Roy SK, Miah M, and Das SK. (2020). A review on corporate environmental reporting (CER): an emerging issue in the corporate world, Can. J. Bus. Inf. Stud., 2(3), 4553. https://doi.org/10.34104/cjbis.020.045053

22. Islam MJ. (2020). Sustainability reporting of banking companies in Bangladesh: a study on environmental aspect, Can. J. Bus. Inf. Stud., 2(2), 35-44.

https://doi.org/10.34104/cjbis.020.035044 
23. Kasavana and Brooks (2001), the effect of emarketing on consumer behavior in hospitality; Tourism \& Hospitality Management.

24. Kendall, Stephanie D. (2007), Customer Service from the customers Perspective. In Fogli, Lawrence. Customer service Delivery: Research and Best Practices.

25. Kothari R (2004). Research Methodology, Methods and Techniques; second revised edition; New Age International Publisher; New Delhi \& (AMA, 2008).

https://www.modares.ac.ir/uploads/Agr.Oth.Lib.17 . $\mathrm{pdf}$

26. Kotler, P. \& Gary, A. (2005), Principles of Marketing. Eleventh Edition, Northwestern University and University of North Carolina, Prentice, Hall of India, New Delhi.

https://www.pearson.com/us/higher-education/ product/Kotler-Principles-of-Marketing-11thEdition/9780131469181.html

27. Lonelyplanet (2011), Electronic Marketing in hotel industry [internet] Addis Ababa. http://www.lonelyplanet.com/ethiopia/addis-aba ba/hotels

28. Miller J, Doyle BA (1987) Measuring the effectiveness of computer-based information systems in the financial services sector. MIS quarterly, 11: $107-124$. https://www.jstor.org/stable/248832

29. Nebel, Eddystone, C. (1991), Managing Hotel Effectively. Second Edition, Van No strand Reinhold: USA.

30. Owen, Bhris (2015), Pre-Cruise Hotels, Chris Cruises Retrieved December 2016.

31. Parasuraman, A., Zeithaml, V.A. and Berry, L.L. (1985), "A conceptual model of service quality and its implications for future research", Journal of Marketing, 49(4), 41-50. https://doi.org/10.2307/1251430
32. Peštek, A., Čičić, M. (2010) "Practical aspects of e-marketing application in tourism development in Bosnia and Herzegovina", Proceedings of International Conference ICES-Economic Development Perspectives of SEE Region in Global Recession Context “, Sarajevo, October 2010.

33. Rahman MM., and Rahman MS. (2020). Green reporting as a tool of environmental sustainability: some observations in the context of Bangladesh, Int. J. Manag. Account. 2(2), 31-37. https://doi.org/10.34104/ijma.020.031037

34. Sardar S, Hossain ME, Hossain MI, and Islam MS. (2020). Factors affecting visitors satisfaction: an empirical study on the Paharpur Buddha Vihara, Naogaon, Rajshahi, Int. J. Manag. Account. 2(4), 61-73. https://doi.org/10.34104/ijma.020.061073

35. Schneider and Bowen (1995), winning the service game, Harvard business school press. https://doi.org/10.1007/978-1-4419-1628-0_4

36. Sisay (2016), e-marketing and customer satisfaction in four star hotels in Ethiopia.

37. Taylor R. (1990), “An assessment of the relationship between service quality and customer satisfaction in the formation of consumers' purchase intentions", Journal of Retailing, 4(2), 163-178. https://doi.org/10.1016/0022-4359(94)90013-2

38. World Tourism Institution (WTI), European Travel Commission, (2008). Handbook on Emarketing for Tourism Destinations, World Tourism.

https://etc-corporate.org/reports/handbook-on-emarketing-for-tourism-destinations/

39. Zikmund, W. B. \& Carr, G. M., 2010. Business Research Methods. $8^{\text {th }}$ ed. South-Western: Cengage Learning. https://www.cengage.com/c/business-researchmethods-8e-/9781439080672PF/

Citation: Mezgebe A. (2020). Effect of electronic marketing on customer satisfaction: the case of four star hotels in Addis Ababa, Int. J. Manag. Account. 2(4), 74-95.

https://doi.org/10.34104/ijma.020.074095 (9) के 